\title{
Spaces of Mega Sporting Events versus Public Spaces: Qatar 2022 World Cup and the City of Doha
}

\author{
Simona Azzali \\ James Cook University, College of Science and Engineering, Singapore \\ simona.azzali@jcu.edu.au
}

\begin{abstract}
In the last decades, many emerging countries have been staging mega sporting events more and more frequently. Among those nations, Qatar stands out for being the first Arab country to host a FIFA World Cup. With the rationale of diversifying its economy and promoting itself as a tourist destination, Doha, its capital city, has recently staged many international events and is literally under construction, undergoing important changes in terms of transportation, infrastructure, and sports facilities.

While hosting cities and organising committees often promote the supposed benefits of a mega event, experience shows an opposite trend: outcomes from staging major events are mostly harmful, and their effects are planned to last only for a short time. When it comes to sporting events sites, stadiums, and their precincts, they usually become under-used and very costly to maintain in a very short time, and their precincts are completely abandoned.

What will be the destiny of the 2022 World Cup stadiums and infrastructure? How can this event be leveraged as a momentum of experimentation and sustainable growth of its capital city, Doha? Is it possible to transform the Cup's stadiums and precincts into liveable, enjoyable and well-integrated public spaces and neighbourhoods?

This work focuses on the city of Doha, which hosted the 2006 Asian Games and will host the 2022 FIFA World Cup and aims to identify strategies to plan and maximise the postevent use of event sites and venues, more specifically stadiums, to generate more liveable and sustainable public spaces. The article investigates Doha's public spaces, and analyses the government's legacy plans for the 2022 World Cup, with a specific focus on stadiums and their precincts. The research aims to be a warning to future hosting cities and presents a series of suggestions on how to best leverage the stage of mega sporting events to promote healthy and liveable public spaces.
\end{abstract}

Keywords: open public spaces, mega sporting events, sustainable legacies, Qatar 2022, stadiums, Doha, liveability

To cite this article:

Azzali, S. (2019). Spaces of Mega Sporting Events versus Public Spaces: Qatar 2022 World Cup and the City of Doha. The Journal of Public Space, 4(2), 57-80, DOI 10.3289I/jps.v4i2.1 204

This article has been double blind peer reviewed and accepted for publication in The Journal of Public Space.

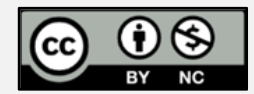

This work is licensed under a Creative Commons Attribution - Non Commercial 4.0 International License https://creativecommons.org/licenses/by-nc/4.0/ 


\section{Introduction}

According to organising committees and hosting cities, mega-events can be very attractive urban policy tools for several reasons: they can confirm or create regional or global status of a city; they can be an opportunity for the construction of new buildings and projects; they can attract visitors and tourists; and they can legitimate a rapid program of infrastructure development. The 1960s were a dividing line in the management of the mega sport events from when they started to be seen as tools for the regeneration and urban transformation of hosting cities. First Rome (1960), and then Tokyo (1964) leveraged the Olympics for the realisation of massive schemes of urban redevelopment, including transportation, road networks, and other major infrastructure (Essex \& Chalkey, 1999; Smith, 2012). The 1992 host of the Summer Olympics, Barcelona, became another milestone in the history of sports mega-events. As many researchers underlined (e.g., Pitts and Liao, 2009; Smith, 20I2), the Games was the occasion for Barcelona to revitalise declining parts of the city and regenerate entire brownfield areas. However, the real effectiveness of such a program to rebuild a city requires a strong plan and legacy strategy. If Barcelona succeeded, other experiences show that outcomes from staging major events are mostly harmful, and their legacies are planned to last only a short time. These negative outcomes are even exacerbated if it is considered how sports facilities and event sites are utilised once the event is over: sports venues are usually under-used and very costly to maintain, while their neighbourhoods are underutilized and become abandoned pieces of cities (Azzali, 2019a; Azzali, 20I7a; Azzali, 2017b).

The Persian Gulf countries are not an exception in the desire of staging mega-events, being an area characterised by a massive sportification (Amara, 2005), with a significant rise in the number of international sport events held (e.g., Doha Moto GP and Bahrain International Formula One Grand Prix). In the case of Doha, the phenomenon of sportification is translated into the desire of transforming the city into a sporting hub. Sport also plays a key role in the 2030 Qatar National Vision, in which sports tourism is indicated as an example of economy diversification from the oil-based model (QSDP, 2009). Finally, during the last ten years, Doha has made bids for and staged many megaevents. The process of transforming itself into an international sporting hub started with the Asian Games in 2006 and will culminate with the host of the 2022 World Cup. Since the stage of the Asian Games, the city has faced critical urban transformations (Azzali, 2016). Four new metro lines, new roads infrastructure, and, most importantly, eight stadiums are currently under construction. The Cup has been envisaged by the Qatari Government to trigger important urban mega-projects and to shift toward a more sustainable model of city.

But what will be left after the 2022 World Cup? How are the eight stadiums and their precincts going to be utilised in the long run? What will be their future? How can site venues and surrounding areas be transformed into meaningful public open spaces (POS)? Is their legacy beneficial in a long-term perspective?

Since Doha shows a lack of public open spaces within its boundaries, is it possible to leverage the 2022 World Cup and other major sports events to promote the implementation of sustainable and liveable POS in the city? What are the legacies planned for the 2022 World Cup in terms of POS? How can the post-event usage of the stadiums utilised for the tournament and their neighbourhoods be maximised? 
By investigating Doha's public spaces, planning practice, and 2022 World Cup's legacy plans, the research aims at deriving some of the recurrent mistakes and malpractices of hosting cities, and helping those cities and organising committees to best leverage the stage of mega sporting events. This roadmap is mainly tailored to Doha and other hosting cities in the Gulf Region, with the aim of adding to the discourse on how to promote healthy and liveable public spaces as legacies of mega sporting events.

\section{Methodology}

In the effort of the Qatari government to transform Doha into a more sustainable and liveable place, some major issues related to planning capability, transportation, and the lack of public spaces accompanied the rapid growth of the city (Azzali and Tomba, 2018). In the first part of the article, the research briefly introduces main public spaces in Doha and their locations. Subsequently, the role of sporting events in Qatar government's strategy is investigated with particular reference to their role in Doha's planning and development. The research covers the city's strategy of sportification by reviewing the planned legacies of the 2022 Qatar World Cup.

After a review of the bid process, the article continues with an overview of the precincts of the eight stadiums involved in the tournament and concludes with an analysis of current malpractices.

Data were collected through site visits and interviews with experts, , and from content analysis of official reports, websites, and newspaper articles. The site visits allowed gaining awareness on the stadiums' precincts and a better understanding of the context in which the venues are located in terms of services, transport system, and future development. At the same time, five interviews were performed with experts in the field. The interviews covered three main areas: a personal definition of legacy; best and worst practices of Doha's World Cup planning, pitfalls and main achievements; and personal opinion on how different hosting cities (i.e. developing vs. developed cities) and different sport events (i.e. Olympics vs. World Cups) can achieve/promote beneficial long-lasting and sustainable legacies.

\section{The city of Doha: Public spaces, planning practice, and the role of sports in its strategic vision}

Doha, capital city of Qatar, is a small and narrow country facing the Persian Gulf, between Saudi Arabia and Iran. Doha was a sleepy and tiny urban settlement with an economy based on fishing and pearling until the 1970s, when the discovery of first, oil, and then gas, triggered an unprecedented rapid urbanisation process. Since the 1970s, Doha has transformed itself from a small vernacular village into an emerging international urban centre with a population of two million residents (QSA, 20I5). With more than a hundred different nationalities inhabiting its territory, it is a multi-ethnic centre, home to a large community of expatriates. Foreigners account for about $85 \%$ of its population, with the number of Qataris nationals being about 300,000 (QSA, 2015). After a first urbanisation process linked to the increasing oil production, Doha is now facing a second fast urban growth led by a new development strategy, which has been implemented to diversify its economy. Tourism has been identified as a fundamental 
pillar to diversify the local economy as well as brand the city to attract new international investments. Indeed, the government is focusing on transforming Doha into a cultural, as well as a sports centre, by hosting many international events like the upcoming 2022 World Cup (QSDP, 2009; Qatar Tourism Authority, 20 I4). In the government's effort to transform Doha into a more sustainable and liveable place, some major issues related to planning capability, scarce public transportation, and the lack of public spaces accompanies the rapid growth of the city. For example, the expansion into large areas of the desert has created urban sprawl instead of a city with delimited boundaries and specific characteristics. This feature is functionally connected to the intensified use of private cars. As Adham (2008) explains, priorities in city planning were given to facilitate the daily use of the car by individual commuters on a large scale. The city is experiencing an extremely rapid horizontal growth. In this context of massive urbanisation, sprawl, and dependence on private vehicles, environmental issues, social inequalities and physical fragmentation are three main consequences to the rapid motorisation of Doha. The results are a lack of walkability and pedestrian paths, and, also, of public and communal spaces for residents.

\section{Doha's public spaces: Few and scattered around the edges of the city}

Liveable, available and accessible open spaces contribute to the overall quality of the urban environment. However, decision makers seem to forget their importance when examining and debating choices related to land use and the enhancement of the public realm, especially in the absence of urban design strategies and guidelines (Salama \& Azzali, 20I5). The relevance of open public spaces is related to their characteristic of satisfying many human needs and providing moments of interaction among citizens (Carmona, 20I0). In public spaces, people can meet and interact, experience social and spontaneous forms of learning and confrontation, especially among citizens who share diverse culture and habits (Elsheshtawy, 20I I). Many scholars focused on the social impact of public spaces. Gehl (1987), for example, describes open spaces as places where people can perform both optional and necessary activities, like going to school or work, or simply reading, walking, sitting or relaxing. All these activities are made possible by the quality and the features offered by these places (Salama \& Azzali, 20I5). Creating high quality open spaces is essential for the wellbeing of people, and sportsthemed areas can play an important role in it. For example, they can be used for physical activities, offering beneficial opportunities to improve fitness and health, especially when the average low active lifestyle in cities, and the rising number of people with heart disease and obesity are considered. To be successful, local governments should avoid creating underutilised, artificial areas, by building urban sport facilities designed to welcome many types of users, and which are flexible and easily accessible to ordinary people. Brown et al. (2000) suggest integrating them with residential and retail activities and facilities, while Smith (2010) proposes mixed-use districts with sport at their centre, and strongly advises implementing areas that are not simply a stadium with a few other iconic facilities around it, but districts with multi-functional activities in the form of shops, business and residential units. All this can lead to the implementation of areas fully integrated with the city, leading to social development. 
In Doha, the only few open public spaces (POS) available are scattered around the peripheries (Figure I), far from one another, and their quantity is not enough to cover the need of the population. Major POS within Doha include the Corniche and the Museum of Islamic Art (MIA) Park, Al Bidda Park, the Pearl, Katara, the Aspire Zone and Park, Al Sadd, Souq Waqif, Msherieb. New additions include the recently opened Sheraton park near Corniche, and, outside Doha, Al Khor Park and AI Wakrah Souq. Oxgen Park in Education City is under construction (Figures I and 2). Figure 2 shows a matrix summarising the profile of main POS. The matrix represents a condensed descriptive profile of each space, which includes a profile of urban typology, accessibility to peoples and cars, type of users of the spaces, and types of activities performed in the space. While the type and uses of spaces vary extensively, establishing a profile of existing public spaces helped to map the need of different socioeconomic groups of residents.

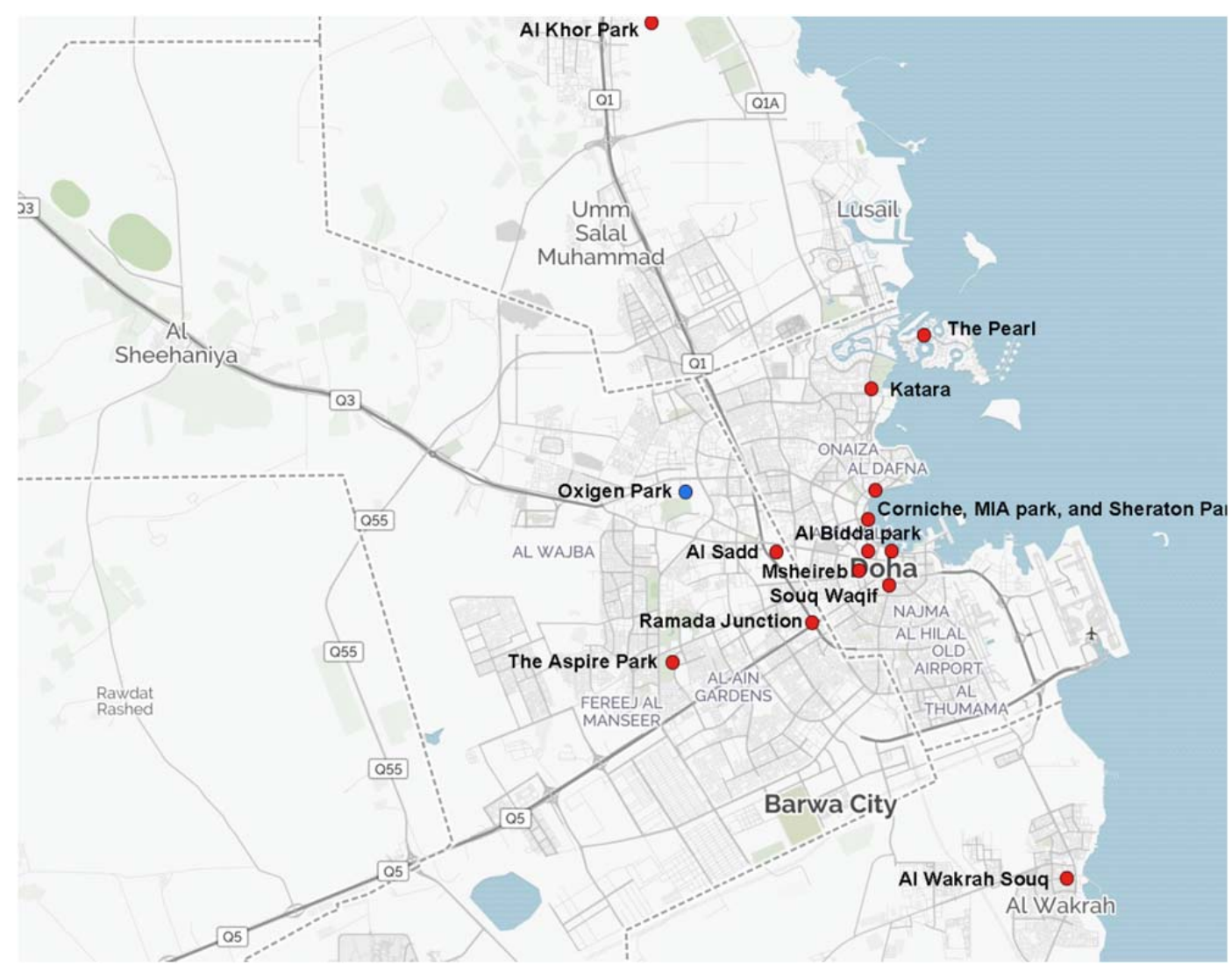

Figure I. The major POS in Doha (source: adapted by the author from Google Maps).

Hence, the realisation of new open public spaces, and among them the implementation of sports areas, is essential for the well development of Doha's urban form and the quality of life of its citizens. This growing demand within Qatar for more facilities for the sports and events industry is even more significant considering the high rate of obesity and diabetes among the youth in the Arabian Peninsula (Amara, 2005). It is underlined by the Qatar National Vision 2030, which stresses the importance of good health habits and actions to encourage local residents to lead a more active lifestyle (QSDP, 2009). 
Doha has to address this lack, but the new spaces need to be physically integrated with the city and avoid any form of isolation, segregation and over regulation. Finally, open spaces should lead to societal development, for example, being the occasion of encounter and exchange, but also encourage sports for all and enhance the overall wellbeing of its inhabitants (Amara, 2005). Major sports events, such as the upcoming 2022 World Cup, if well leveraged, could contribute to partially solve the lack of public spaces and contribute to improve the overall wellbeing of Doha's residents.

\begin{tabular}{|c|c|c|c|c|c|c|c|c|c|c|c|c|c|c|c|c|c|c|c|c|c|}
\hline \multirow[t]{2}{*}{$\begin{array}{l}\text { Space } \\
\text { (Name and Place) }\end{array}$} & \multicolumn{6}{|c|}{$\begin{array}{l}\text { Spatial Typology } \\
\text { Describing the spatial } \\
\text { environment- } \\
\text { Architecture/Urban }\end{array}$} & \multicolumn{3}{|c|}{$\begin{array}{l}\text { Accessibility } \\
\text { Context around the } \\
\text { space/parking }\end{array}$} & \multicolumn{2}{|c|}{ People } & \multicolumn{4}{|c|}{$\begin{array}{l}\text { People } \\
\text { Typologies visiting } \\
\text { the space }\end{array}$} & \multicolumn{6}{|c|}{$\begin{array}{l}\text { Activities } \\
\text { Nature and Type } \\
\text { of Activities }\end{array}$} \\
\hline & 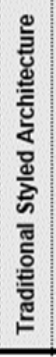 & 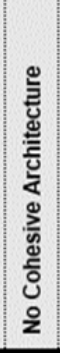 & 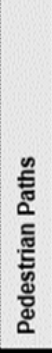 & 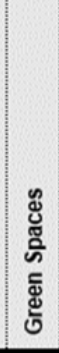 & 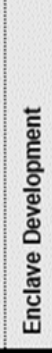 & 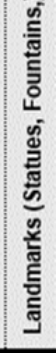 & 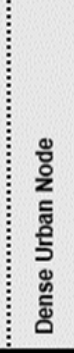 & 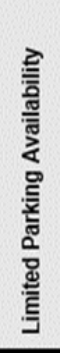 & 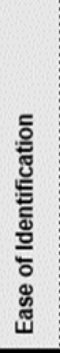 & 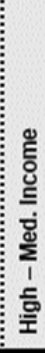 & 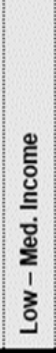 & : & 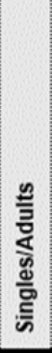 & 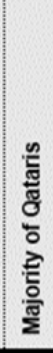 & 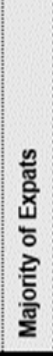 & 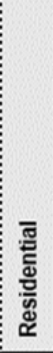 & 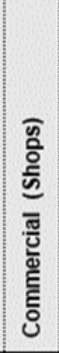 & 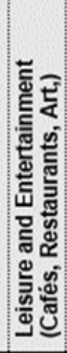 & 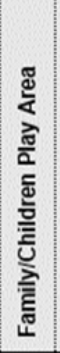 & 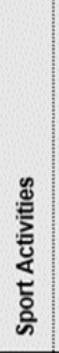 & 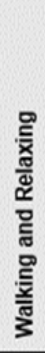 \\
\hline Katara Cultural Village & $\bullet$ & & $\bullet$ & & $\bullet$ & & & $\bullet$ & $\bullet$ & $\bullet$ & & $\bullet$ & $\bullet$ & $\bullet$ & $\bullet$ & & & $\bullet$ & $\bullet$ & & $\bullet$ \\
\hline The Pearl & & & $\bullet$ & & - & & & $\bullet$ & - & $\bullet$ & & • & $\bullet$ & • & - & $\bullet$ & - & - & & & • \\
\hline Sheraton Park & & & $\bullet$ & $\bullet$ & & & & & & $\bullet$ & $\bullet$ & $\bullet$ & & & $\bullet$ & & & $\bullet$ & $\bullet$ & $\bullet$ & $\bullet$ \\
\hline Corniche & & & $\bullet$ & & & $\bullet$ & & $\bullet$ & & - & $\bullet$ & $\bullet$ & & & $\bullet$ & & & $\bullet$ & & $\bullet$ & $\bullet$ \\
\hline MIA Park & & & $\bullet$ & $\bullet$ & & $\bullet$ & & & & $\bullet$ & $\bullet$ & & $\bullet$ & & & & & $\bullet$ & & $\bullet$ & $\bullet$ \\
\hline Al Bidda Park & $\bullet$ & & & $\bullet$ & & $\bullet$ & & & & & $\bullet$ & $\bullet$ & & & $\bullet$ & & & $\bullet$ & $\bullet$ & $\bullet$ & $\bullet$ \\
\hline Souq Waqif Area & $\bullet$ & & $\bullet$ & & $\bullet$ & & & $\bullet$ & $\bullet$ & $\bullet$ & & & & $\bullet$ & $\bullet$ & & $\bullet$ & $\bullet$ & & & $\bullet$ \\
\hline Aspire/Nillaggio & & & $\bullet$ & $\bullet$ & & & & & $\bullet$ & & & $\bullet$ & & $\bullet$ & $\bullet$ & & & & $\bullet$ & $\bullet$ & $\bullet$ \\
\hline Msheireb & $\bullet$ & & & & & & $\bullet$ & $\bullet$ & & & $\bullet$ & & $\bullet$ & & & & $\bullet$ & $\bullet$ & & & \\
\hline Al Sadd & & $\bullet$ & & & & & $\bullet$ & & & & & & - & & $\bullet$ & & $\bullet$ & $\bullet$ & & & \\
\hline Al Wakra Souq & & $\bullet$ & & & & & $\bullet$ & $\bullet$ & & & & & $\bullet$ & & $\bullet$ & & $\bullet$ & $\bullet$ & & & \\
\hline Al Khor Park & & & - & $\bullet$ & & & & & - & & & - & & - & $\bullet$ & & & & - & $\bullet$ & - \\
\hline
\end{tabular}

Figure 2. Summary of the characteristics of Doha's main open spaces (source: adapted from Salama and Azzali, 2015).

\section{The evaluation of the bid book and the role of the Supreme Committee for delivery \& legacy}

On 2 December 2010, Russia and Qatar were awarded the 2018 and 2022 World Cups respectively (FIFA, 20I0). Qatar is the first Arab country to be awarded a FIFA World Cup. Former president Sepp Blatter endorsed the idea of having a World Cup in the MENA region, and, in April 2010, said, "The Arabic world deserves a World Cup. They have 22 countries and have not had any opportunity to organise the tournament". He 
also added "When I was first in Qatar there were 400,000 people here and now there are 1.6 million. In terms of infrastructure, when you are able to organise the Asian Games [in 2006] with more than 30 events for men and women, then that is not in question" (Qatar Gulf News, 20I0).

An analysis of the bid book allows the understanding of the country's legacy strategy. First of all, the bid's concept tries to be in line with the 2030 Qatar National Vision, the national comprehensive blueprint. For example, the bid book focused strongly on the development of new transport and infrastructure. Indeed, at the time of writing, four metro lines are under construction and planned to be partially ready for 2019.

Additional infrastructure included and promised in the bid book were the new airport, Hamad International Airport, opened in mid-2014, a new port, opened in early 2017 , and an overall improvement of roads condition. The bid book also promised that social and human development initiatives would be carried out, aiming to enhance the human condition through local and global football-based initiatives. The bid book committed to develop initiatives related to the development of football facilities and opportunities for women. Regarding costs and expenditures, a stadium construction and renovation budget of approximately USD 3 billion has been projected (FIFA, 2010). In April 20II, the Qatar 2022 Supreme Committee (SC) was founded to manage and deliver the event. The Committee changed its name to Supreme Committee for Delivery \& Legacy in January 2014, to stress the commitment of the country to legacy and sustainability, and to separate the roles of delivery and legacy from the tournament operations and hosting experience. The Supreme Committee for Delivery \& Legacy is tasked with delivering proposed tournament venues and projects for the 2022 competition, while ensuring that its preparations align with Qatar's other development imperatives, as described in the Qatar National Vision 2030 and the National Development Strategy 20II-2016. On the contrary, the Local Organizing Committee (LOC) is the event organiser, and will take over responsibility for event planning, promotion and marketing, as well as operations and all related tournament duties (SC, 2016a).

\section{The stadiums and precincts planned for the 2022 World Cup}

Differently from what affirmed in the bid book, where 12 stadiums were proposed, Qatar is currently building eight stadiums (Figure 3 and Table I), which is the minimum number required by FIFA to host a tournament of 32 teams. Five stadiums (Qatar Foundation, Al Khor, Al Ryyan, Al Wakrah, and Khalifa International Stadium) are currently under construction and all are scheduled to be completed by 2020 . Another three stadiums (Ras Abu Abboud, Lusail, and Al Thumama) are still in the preliminary stages at the time of writing. According to the Supreme Committee of Delivery and Legacy - SC (2016b), all the stadiums and their precincts will be environmentally friendly, targeting LEED and GSAS 4 Star certifications. In addition, the majority of them will be served by the new public transport system that is under construction. According to the bid book, after the end of the World Cup, the upper tiers of at least six stadiums will be dismantled and donated to developing nations, in order to provide them with the means to build new venues. Also, according to SC, the stadiums will be

\footnotetext{
${ }^{1}$ Global Sustainability Assessment System (GSAS) is the first performance-based system in the MENA region, developed for rating the green buildings and infrastructures.
} 
provided with cooling technologies that will be utilised all year-round, regardless of outside temperature and weather conditions.

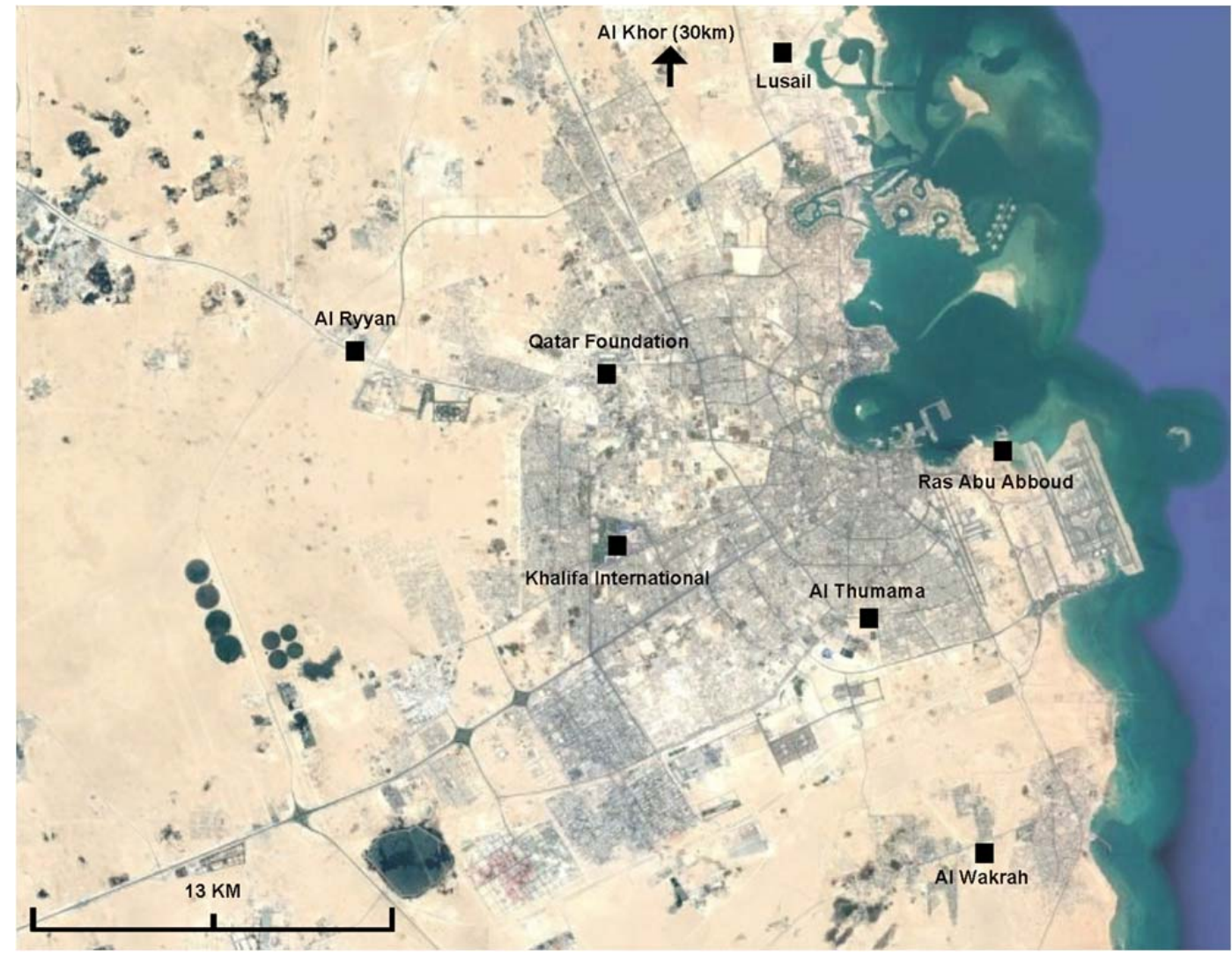

Figure 3. The location of the eight planned stadiums in Doha (source: adapted by the author from Google Maps).

The following section will briefly present the eight stadiums and their precincts'. Data were collected through site visits and interviews with experts, performed between September and December 2016, and from websites and newspaper articles. The site visits allowed gaining awareness of the stadiums' precincts and a better understanding of the context in which the venues are located in terms of services, transport system, and future development.

\section{Lusail stadium}

Lusail is a new development that is under construction in the North of Doha, near $\mathrm{Al}$ Qutaifiya bay, and it is designed to accommodate between 200,000 and 250,000 inhabitants in a $35 \mathrm{~km}^{2}$ area. This neighbourhood will host residential areas, two marinas, seaside resorts located on offshore islands, shopping centres, and other luxury activities. The red metro line and four lines of light rails will reach the neighbourhood. Lusail is planned around mixed-use developments (Figures 4) with the aim of creating integration, diversity, and sustainability (Lusail City, 2016). Not far from Lusail, there is the international circuit of Losail that hosts one round of MotoGP every year, a multi- 
sports complex, built on the occasion of the 2015 World Men's Handball Championship, and a golf course.

The stadium, built from scratch, will have a capacity of 80,000 and is set to host the opening and closing ceremonies as well as the final match. It is located in the middle of Lusail development (Figure 5).

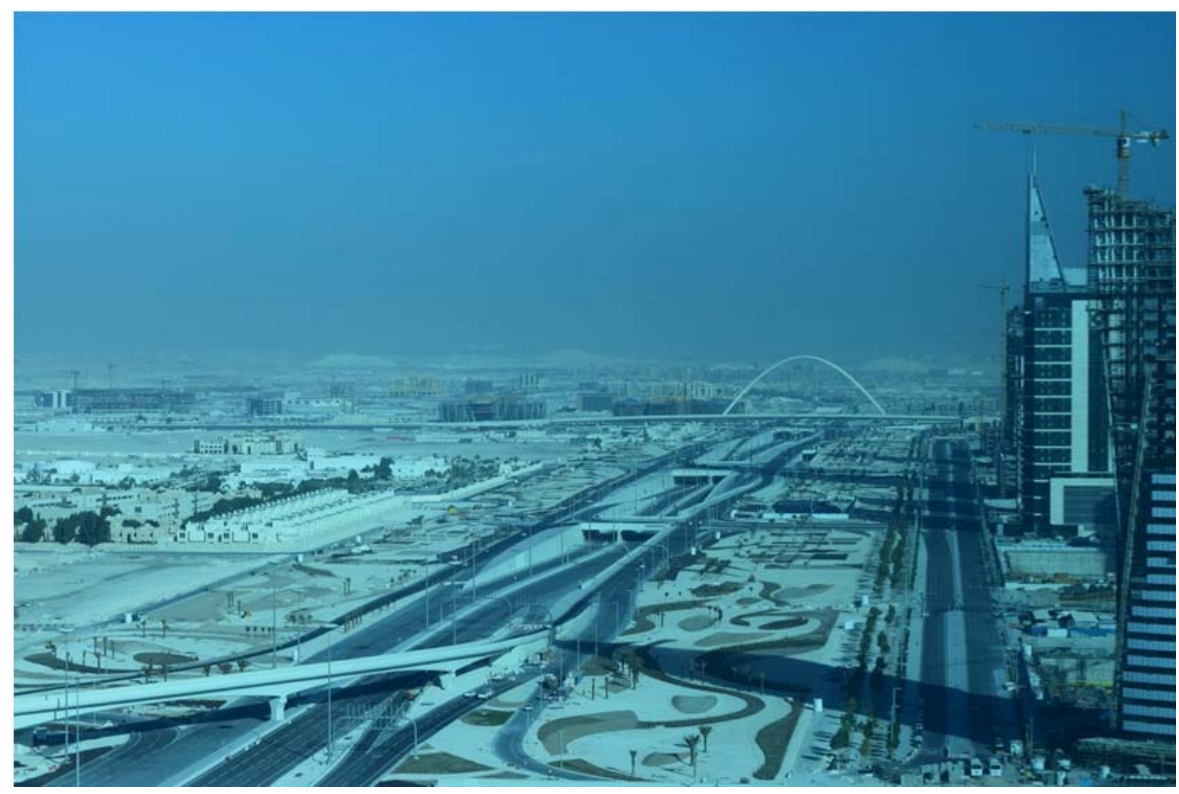

Figure 4. The area of Lusail under construction.

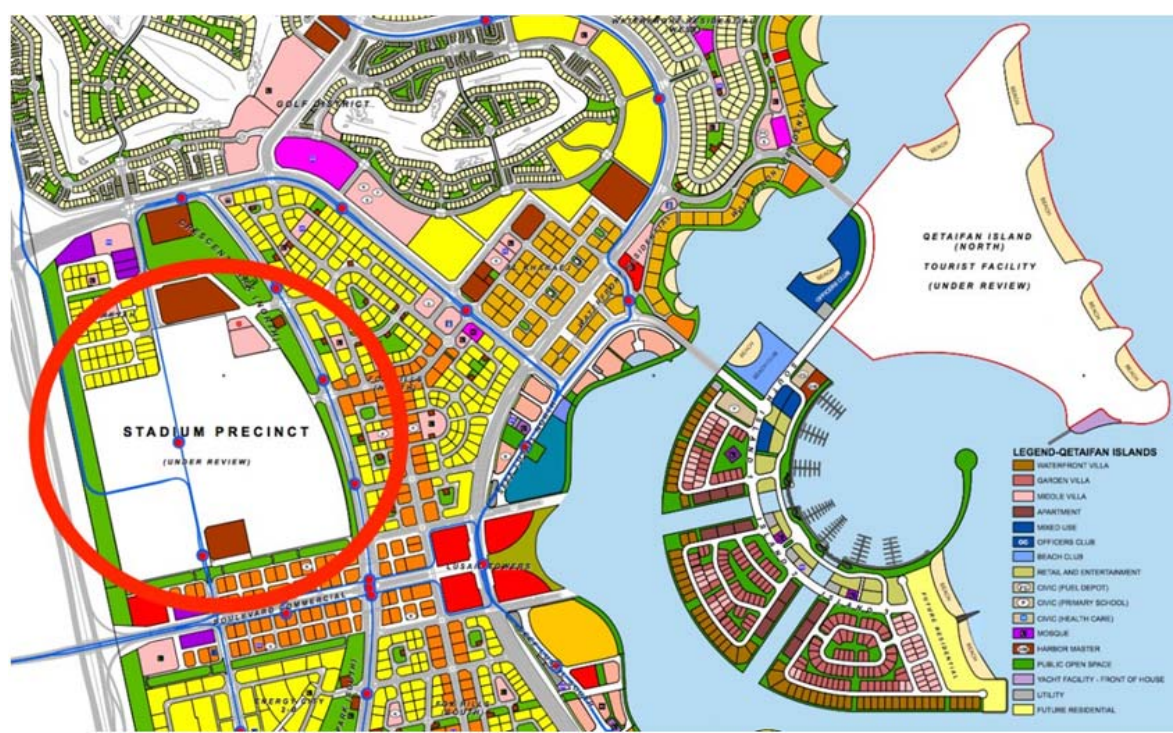

Figure 5. The Lusail Master Plan (Source: Lusail website). 


\section{Al Bayt stadium, Al Khor}

Al Khor is a small coastal town located around $40 \mathrm{~km}$ north of Doha. Its main vocation is to serve as a residential area for medium and low-income labourers. Its population is about 202,000 , with some of 168,000 people living in labour camps and 34,000 residents in households.

The new stadium will have a capacity of 60,000 seats, reduced to 38,000 in the legacy mode (Figures 6 ), and will host matches up to the semi-finals. The venue is planned to have a modular structure. In the bid book, its upper tier was presented to be made of removable seats, and, like a true nomad's tent, it will be 'portable'.

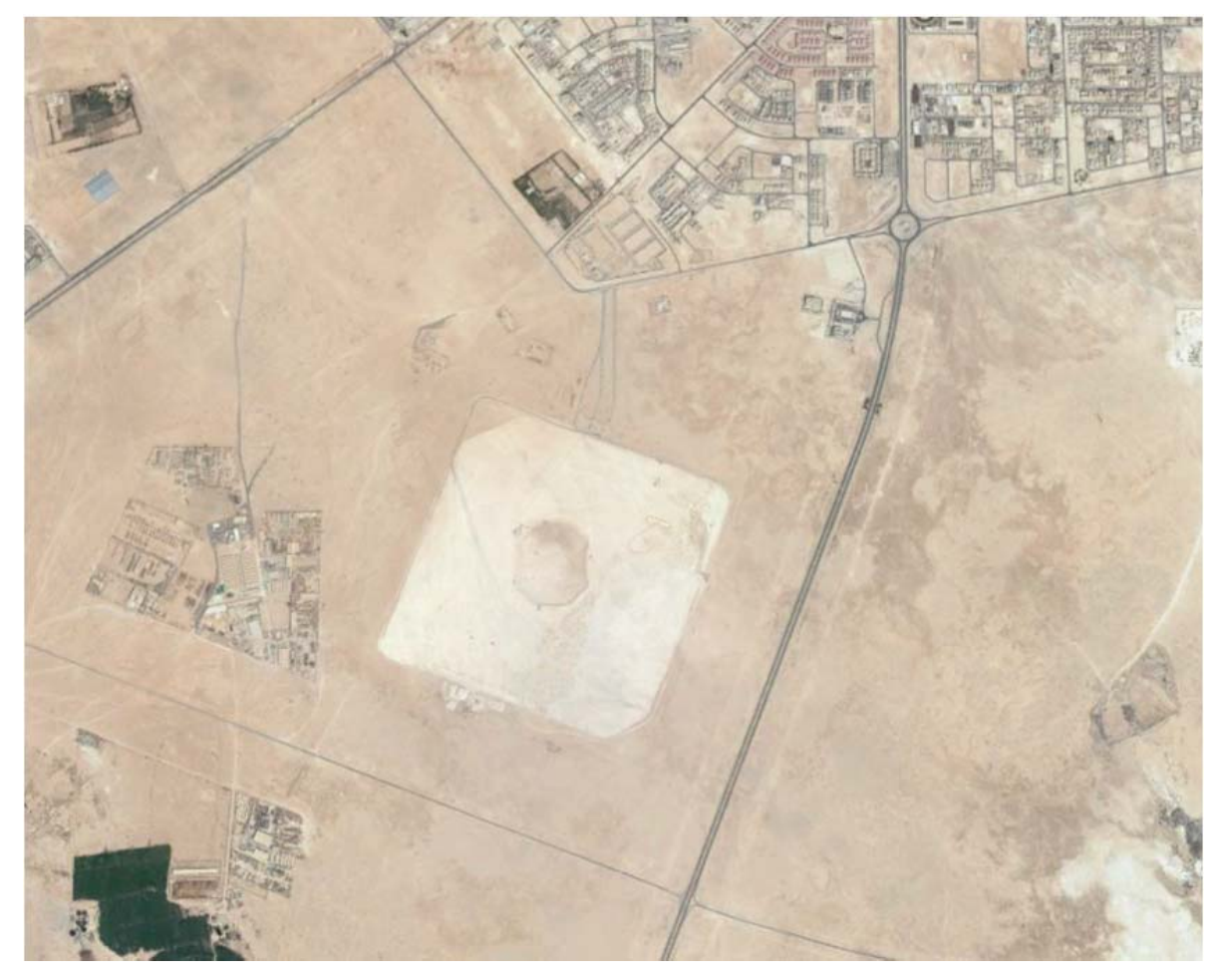

Figure 6. Aerial view of Al Khor stadium (Adapted from Google Earth).

\section{Al Thumama Stadium}

Al Thumama is a residential neighborhood located in the southern part of Doha between E-ring and F-ring roads. It has an overall dimension of $7.0 \mathrm{~km}^{2}$ and a population of 2I,367 residents (Ministry of Development Planning and Statistics, 2015). The stadium, a new venue of 40,000 seats, will be located between E-Ring and F-Ring Roads, just behind the church complex and the Industrial Area, in an area of 5I5,400 sq. meters that already hosts the Qatar Football Association Technical Committee and four training pitches. The area will not be commutable by any of the three metro lines under construction.

\section{Al Wakrah stadium}

Al Wakrah is located $15 \mathrm{~km}$ south of the centre of Doha. It was originally a small fishing and pearling village with an overall population of around 300,000 residents currently 
(Ministry of Development Planning and Statistics, 2015), although about 220,000 people out of this number live in labour camps, and only 80,000 live in households in the city $\mathrm{Al}$ Wakrah. The red metro line will serve the town, with a stop in the north of the city. Al Wakrah's main vocation is to serve as a residential area for medium and low-income labourers.

The stadium is a new venue, around $7 \mathrm{~km}$ away from the metro stop on the red line (Figure 7). It stands near the main hospital and schools, and a mall. The capacity for the World Cup will be 40,000 seats, reduced to 20,000 in the legacy mode. According to the Supreme Committee of Delivery and Legacy (2016b), the upper tier will be disassembled and distributed to developing nations that lack sporting infrastructure. In the legacy mode, the venue will become the new home of Al Wakrah Sports Club.

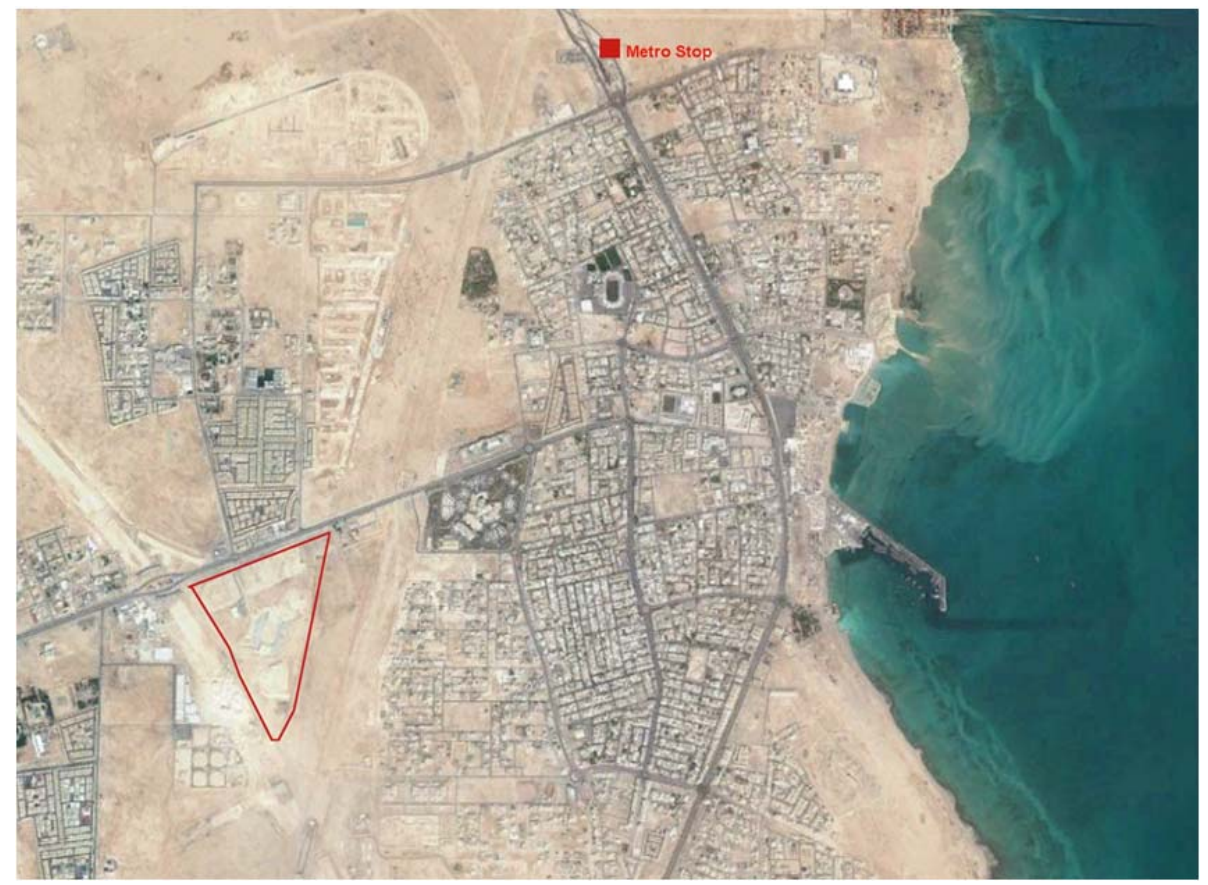

Figure 7. Aerial view of Al Wakrah, with metro stop and stadium's precincts.

\section{Ras Abu Abboud stadium}

Ras Abu Abboud is located in the southeast of Doha's city centre, near to the old airport and the new Hamad International Airport. It has a waterfront location that is visible from West Bay, the new business district of Doha. The site covers an area of about $\mathrm{I} \mathrm{km}^{2}$ and has a population of $\mathrm{I}, 73 \mathrm{I}$ residents (Ministry of Development Planning and Statistics, 2015). According to recent plans, this area will be redeveloped into a new urban neighbourhood, and the Gold metro line under construction will serve it.

However, the site has a strong touristic vocation, as it stands close to the Museum of Islamic Art, the National Museum under construction, and some hotels. In addition, Ras Abu Abboud is also close to the panoramic street Al Corniche, a seven-kilometre costal road, Souq Waqif, and the old port, that will be reconverted into a touristic harbor. 
The stadium will be a new venue, standing over a 450,000 sq. $\mathrm{m}$. site. It will have a capacity of 40,000 seats and will include 6,000 car parks during the tournament and 2,000 in legacy mode.

\section{The Aspire Zone: Khalifa International Stadium}

The Aspire Zone, Doha's sports city, is located peripherally to the city, about $8 \mathrm{~km}$ from downtown, and it covers a surface of $2.31 \mathrm{~km}^{2}$ (Smith, 2010; Figure 8). This was the original site of Khalifa Olympic Stadium, a venue built in 1976 with a capacity of 20,000 seats. The overall shape of the area is designed by taking inspiration from the desert.

The area will be served by the gold metro lines with the stops, Sports City and Al Aziziyah. The stadium, Kahlifa International, has been recently upgraded to a capacity of 40,000 seats. The vocation of the area is to be the main sports hub of the city and to attract other large-scale sporting events to Qatar. Indeed, in September 2019, the stadium was the host venue for the 2019 IAAF World Athletics Championships.

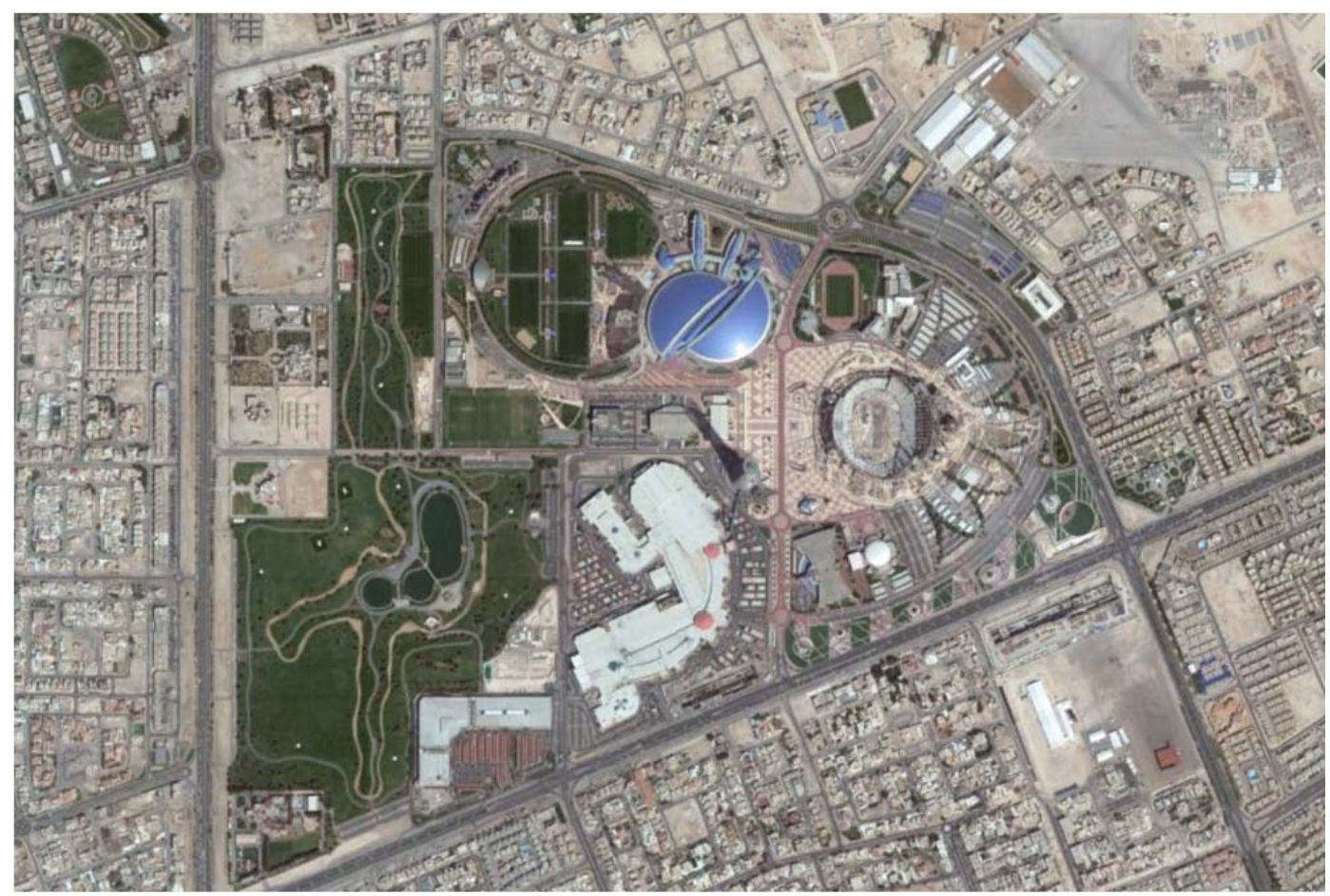

Figure 8. The facilities of the Aspire Zone (source: Google Maps).

\section{Qatar Foundation stadium (Education City)}

Education City (EC) is located in the west side of Doha, and it covers an area of around $14 \mathrm{~km}^{2}$. EC hosts several educational facilities and branch campuses of some American and European universities (Figure 128). The vocation of the area is education and research. Qatar Foundation stadium will be located within the Education City southwest campus, and it will be served by the green metro line. The venue will be built from 
scratch and is expected to be ready by the end of 2019 . Full capacity will be 40,000 seats, reduced to 25,000 in the legacy mode (Figure 129).

\section{Al Ryyann stadium}

Situated near Dukhan Highway and the Mall of Qatar, Al Rayyan stadium will be rebuilt on the former site of the Ahmed Bin Ali stadium which was recently deconstructed (Figure I 30 and I 3 I). The old venue was supposed to be refurbished for the World Cup, but it was demolished because it did not meet FIFA's technical requirements. The stadium will be finished by the end of 2019 and served by the green metro line. The capacity for the FIFA World Cup will be 40,000 seats, reduced to 21,000 after the event. In the legacy mode, the stadium's precinct should include other sports facilities such as an athletics track, tennis courts, cycling and running tracks, cricket pitch, hockey pitch, football training area, aquatics centre, as well as a skating park (SC, 20I6c).

\section{Malpractices and key-issues in the $\mathbf{2 0 2 2}$ World Cup}

The development of sustainable legacies from the stage of mega sports events is a difficult task. Indeed, the achievement of a positive sustainable legacy requires cooperation and resource sharing from a variety of event stakeholders (Leopekey, 2013). As a result of a series of site visits around Doha's stadiums precincts, interviews with experts in the field, and the investigation of the process of sportification of Doha, several implications arose. Following the framework developed in Azzali (2019b), six main attributes, in the form of opposite terms, were utilised to assess Doha' stadiums and precincts. This set of attribute includes temporary vs. permanent; already existing vs. new infrastructure; integration vs. divergence; public vs. private; local needs vs. event needs; high vs. low responsiveness to unplanned or unintended events. The framework aims at providing guidance to host cities in the planning of a mega sport event, specifically, for the post-event use of sports clusters. The list particularly intends to be a moment of reflection on the identity and role of sports venues and event sites. Cities, especially in emerging countries, are increasingly interested in bidding and hosting megaevents, and it has become strategic to implement strategies to maximise the benefits from their stage, and planning and implementing positive, sustainable and long-lasting legacies.

The following is a list of some critical issues that emerged.

\section{Temporary vs. Permanent}

A first element to consider when planning a major sport event site is the right balance between ephemeral and permanent components. In particular, temporary infrastructure is a solution that is not taken into account enough in event planning. Jürgen Müller, the head of planning and infrastructure at the 2022 World Cup and at FIFA, during the three-day World Stadium Congress, held in Doha in May 2016, stated that sports venues should take into account local needs, and that some requirements could be met and declared through temporary solutions. Indeed, he said, "Don't build stadiums that (will) not (be) filled by your leagues or your teams. FIFA would like to avoid, by all means, white elephants" (Doha News, 2016a). However, Qatar has a small population 
(about 2,500,000 people, the majority of them living in Doha), and already has enough stadiums for its major league, the Qatar Stars league.

Table I. Details of the eight stadiums under construction (source: author)

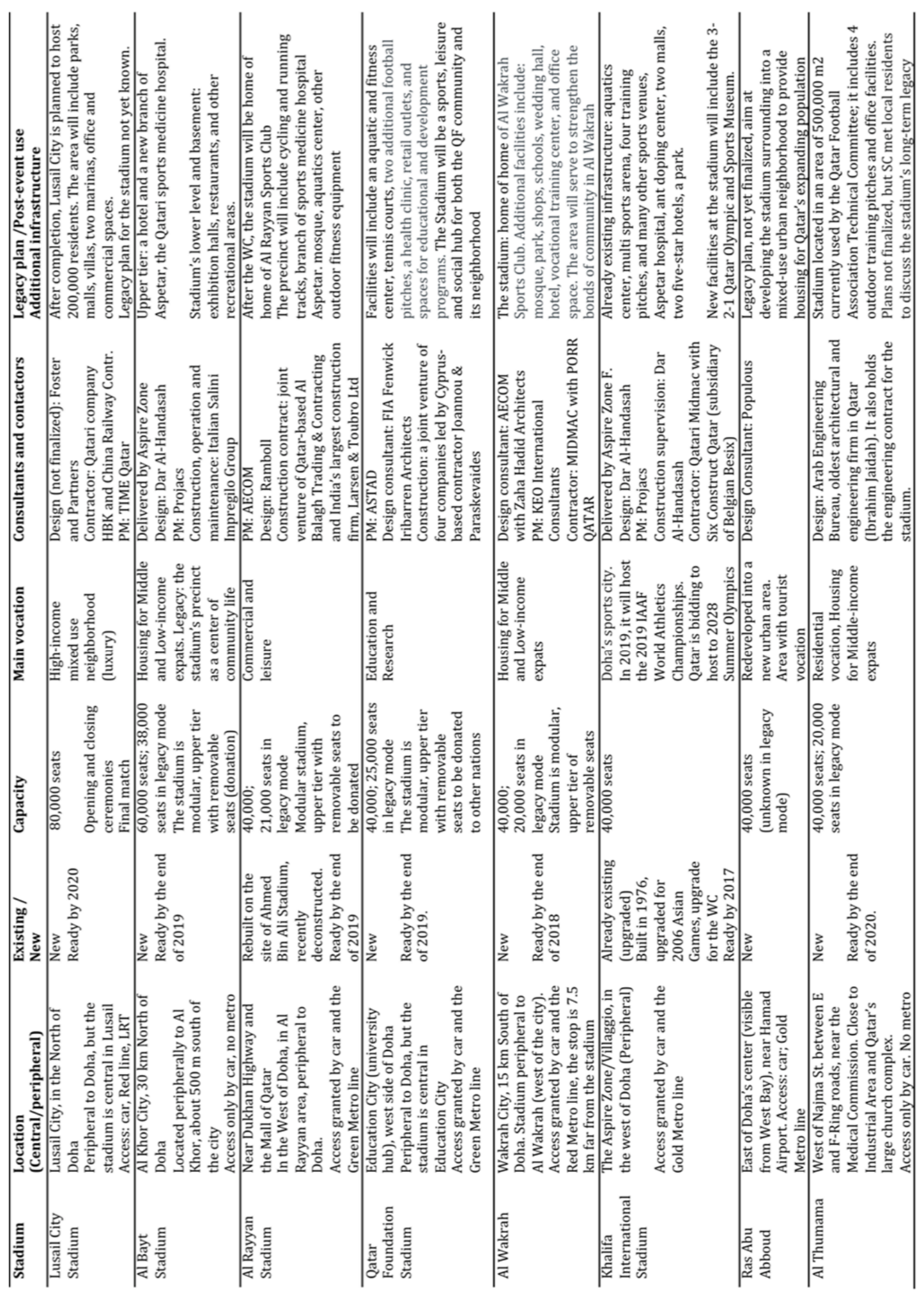

70 | The Journal of Public Space, 4(2), 2019 | ISSN 2206-9658

City Space Architecture / UN-Habitat 
All the eight stadiums that are under construction for the 2022 World Cup are meant to be permanent; although for five of them (with the exclusion of Lusail, Ras Abu Abboud, and Khalifa International stadium), plans, in the legacy mode, include the removal of the upper tier seats. All the stadiums are designed as modular structures and should be downscaled to half the capacity after the tournament. In the bid book, it was also promised that those tiers and modular sections would be used to construct stadiums in developing countries. It is also said that venues' precincts will be dedicated to sports and leisure, with hotels, shops, restaurants, and other activities that will be placed both inside and outside the stadiums. According to SC (20I6b), the precincts will host schools, parks, and other mixed-used facilities according to local needs. Stadiums should also house Qatar residents in the event of a national emergency to serve as temporary accommodation, during earthquakes or other natural disasters (Doha News, 20I6b). These initiatives are meant to improve the number and the quality of open spaces and public services in Doha. However, the plans are vague and not yet finalised for the majority of the cases. There is no clue about how much the downscale of the stadiums will cost, and how long it will take to complete the process. There are also no precise indications on the use of the dismantled upper tiers and which countries should receive them. Especially for venues as the Lusail Stadium, which will have a capacity of 80,000 seats, detailed plans on the legacy mode are vital, as the country does not need such a huge infrastructure, and the risk of becoming a white elephant is very high. In addition to sports infrastructure, Qatar also needs to upgrade its touristic and hotel infrastructure. With a current number of 20,000 serviced apartments and hotel rooms available, Qatar needs to meet the FIFA requirement of 60,000 rooms before 2022 . To overcome the absence of hotel rooms, the country is implementing wise initiatives such as allowing residents to temporarily rent out their rooms through services such as Airbnb, utilising cruise ships, and building temporary tent camps in the desert to accommodate tourists during the tournament (Doha News, 2016c). Temporary solutions here seem wise to prevail permanent ones.

\section{Already existing vs. new infrastructure}

Very often, mega sports events generate white elephants and underutilised venues. Hosting cities should consider accurately balancing new and existing infrastructure in their plans for the event, both regarding sports venues and city infrastructure (i.e. transport and mobility). In the case of Qatar, with the exception of Khalifa International, which is under refurbishment to be upgraded to 40,000 seats, all the other planned venues are new and built from scratch. Three stadiums with a capacity of 40,000 seats each (Al Wakra, Al Thumana, and Ras Abu Abboud) will be located in the area of the new airport, within a radius of $15 \mathrm{~km}$, and, with the exclusion of Al Khor, which is placed $30 \mathrm{~km}$ north of Doha, the average distance between two contiguous stadiums will be around $16 \mathrm{~km}$ (Table 2). For a country that already has enough venues for its major league and does not have a strong football tradition, these numbers are impressive.

In addition to the stadiums, Qatar is also building a massive supportive infrastructure for the tournament. First of all, improvements in the transport system are underway. Indeed, in May 2014, Hamad International, the new airport, opened, while the first phase of the new port opened in mid-20I7. 
Table 2. Average Distance between contiguous stadiums (distance calculated by the author using Google Earth).

\begin{tabular}{l|c}
\multicolumn{1}{c|}{ Stadiums } & Distance \\
\hline Al Wakrah - Al Thumama & $15 \mathrm{~km}$ \\
\hline Al Thumama - Ras Abu Abboud & $10 \mathrm{~km}$ \\
\hline Al Thumama - Khalifa International & $15 \mathrm{~km}$ \\
\hline Khalifa International - Qatar Foundation & $10 \mathrm{~km}$ \\
\hline Qatar Foundation - Al Ryyan & $26 \mathrm{~km}$ \\
\hline Qatar Foundation -Lusail & $20 \mathrm{~km}$ \\
\hline
\end{tabular}

In addition, three metro lines are under construction and will be ready before the beginning of the tournament, while roads will also be upgraded or newly built. Besides the transport system, the country is also boosting its tourist capacity with the construction of new hotels and serviced apartments to reach the number of 60,000 rooms that is required by FIFA, although in the bid book, Qatar included plans of 100,000 rooms (FIFA, 20I0). Qatar is a small country, similar to a city-state, with poor football infrastructure and is not yet prepared to host such a kind of event. These data show that the approach of utilising mega-events as a catalyst for urban development and regeneration can be extremely risky, especially for emerging countries. Indeed, implementing massive construction plans, developing both new sports venues and new city-level infrastructure at the same time may lead to financial disasters. As the case of the 1976 Montreal Olympics exemplifies, poor management and great expenditure caused a huge long-term debt. More recently, the 2014 Olympics in Sochi owns the record of being the most expensive of all the Winter Games, and its legacy was mostly negative. The city spent over USD 50 billion for building new venues and transporting infrastructure. Three years after the end of the Games, the majority of the stadiums are closed or under-utilised, while the high-speed railway new lines are partially closed (Müller, 20I4).

\section{Integration vs. Divergence}

Qatar's government has introduced a comprehensive and holistic blueprint few years ago with ambitious strategies related to the development of its environment, society, and the economy. This program, called Qatar National Vision 2030 (QNV 2030), is asked to play as the major agent for developing and improving Doha's urban governance for the upcoming years. Its implementation consists of design and realisation of a comprehensive master plan, which is required to guide Doha's urban development toward more consolidated structures (GSDP, 2009). In QNV 2030, the 2022 World Cup is meant to facilitate the implementation of this ambitious program, by catalysing important infrastructure such as the transport system, and promoting healthy lifestyles through sports. In this sense, the tournament can contribute to the physical integration of new neighbourhoods in the city. Indeed, six stadiums out of eight can be reached via 
the new metro system, and many roads will be upgraded or opened (Figure I 33 for the metro system). So, after the tournament, commute to and from Doha will be easier. However, from a physical point of view, a risk associated with event sites is that they often allow the creation of 'islands of regeneration' or 'bubbles' (Carrière and Demaziere, 2002): event venues are physically separated and detached from the rest of the city, and they become an obstacle to the integration they are expected to implement. One of the reasons for that is that these areas are designed without any consideration of their interaction with the city and on how they will affect the surroundings. The design effort is devoted exclusively to a specific area, without examining the impact on the whole city. Also, new stadiums need to be carefully planned. Stadiums are indeed the dominant facility in all mega sports events, but they are also the most problematic venues in the post-event usage. Usually they are enormous facilities that 'struggle' to find their place in the city and they alternate short periods of extreme congestion on match days with long periods when they are totally empty or under-utilised. In many other occasions, the stadium is almost abandoned after the end of the event, and this risk is very high in Doha.

From a social point of view, Qatar is an emerging but wealthy country, and its citizens are among the richest in the world. In this sense, with regards to local residents, Qatar will not face the same issues as its predecessors (i.e. Brazil, Russia, South Africa). The highest social cost is related to the work force utilised for the preparation of World Cup infrastructure (i.e. South East Asian labourers involved in the building of the stadiums and transport infrastructure). Indeed, just after the award, a number of concerns regarding human right issues arose, in particular, regarding working conditions and the hiring system. Also, in March 2017, the International Labor Organization (ILO) decided to continue monitoring Qatar for human rights violations till November 2017. After this time, ILO will revisit to open a Commission of Inquiry, its highest investigative mechanism (Doha News, 2017).

Finally, regarding the environment, the bid promised Qatar to be the first carbon neutral tournament, and that new technologies and materials would be used to build sustainable stadiums. In this sense, the bid also promised the stadiums to be GSAS certified. However, in spite of GSAS certification, sustainability will be achieved only if the venues are fully used after the tournament. Regarding Al Rayyan, the stadium is supposed to utilise about 90 per cent of the materials derived from the deconstruction of the old stadium (SC, 20I5). The old venue was supposed to be refurbished for the World Cup, but it was demolished because it did not meet FIFA's technical requirements.

\section{Public vs. Private}

Who will be the beneficiaries from the stage of the 2022 World Cup? And who will pay for it? In any mega event, the right balance between private and public interests should be planned and implemented, by involving local communities in the decisions and panning processes with public participations tools. Qatar is a rich country, and with an average of 133,000 USD, it is the country with the highest GDP per capita in the world.

\footnotetext{
${ }^{2}$ Global Sustainability Assessment System (GSAS) is the first performance-based system in the MENA region, developed for rating the green buildings and infrastructures.
} 
However, Qatar is also a small country and its overall GDP is estimated to about 167 billion USD, less than the 195 billion of Greece, the 370 billion of the Emirates, or the 292 billion of Singapore (The World Bank, 20I5a). Indeed, in the 2015 world GDP ranking by the World Bank (20I5b), Qatar is placed in the 54th place, after countries like Bangladesh, Vietnam, or Peru. Although official data are not available, according to some estimates (Doha News, 20I I; The Telegraph, 20I I), the overall cost of the 2022 tournament will be about 220 billion USD, around 60 times of what South Africa spent in 2010 (estimated in 3.5 billion USD). With a population of around 225,000 Qatari citizens, it means that country will spend more or less 100,000 USD per capita, compared to 73 USD per capita for the 2010 Brazil World Cup, 350 USD per capita for the 2014 Sochi Winter Games, and 54 USD per capita for South Africa (data for Sochi, South Africa and Brazil from Time, 2013). If this amount of money is confirmed, it means also that Qatar will spend more than one year GDP in the tournament. Also, for example, the focus of 2017's budget was to ensure that major projects related to the 2022 tournament proceed as scheduled, with about 50\% of the annual country's budget dedicated to this effort. Since mega sport events expenditure usually does not pay off, especially in the long-term, Qatar should review its strategy and look for positive case studies that associated the construction of a new stadium with more profitable real estate investments. Qatar should look at examples of implemented strategies to minimise the debt incurred for the preparation of the stadiums and the tournament.

\section{Local Needs vs. Event Needs}

Müller (20I5) reminds us of the risk of event take over when dealing with infrastructure related to mega events. He states, "Mega-event priorities often displace long-term urban development priorities. Instead of the event becoming an instrument for urban development, urban development becomes the instrument for the event" (p. 10). The costs presented in the previous paragraph seem to move towards this direction, but other factors also support this statement. Indeed, there is a very recent football tradition in Qatar. The main league, Qatar Stars League, had its first official season only in 1972, and it features 14 teams, with the most recent team founded in 2009. The teams utilise 10 different stadiums for the matches that are considered more than enough for the needs of the league, each with a capacity between 12,000 and 25,000 seats. Qatar had initially promised 12 new stadiums for the World Cup, but, at the time of writing, this number has been wisely reduced to eight. However, even if the number eight is confirmed and the post-tournament plans are approved, according to which the majority of the stadiums would be reduced to half capacity (see Table 3), the number of seats available still would be surprisingly high for a total country's population of 2,500,000 people. Indeed, Qatari nationals are estimated in about 300,000 units, while the number of seats in the legacy mode would be 284,000 , with an availability of about one seat for each Qatari citizen (Table 3). 
Table 3. Stadiums and Capacity (Data source: SC, 20 I 6b)

\begin{tabular}{l|c|c}
\hline Stadium & 2022 World Cup & Legacy mode \\
\hline Khalifa International & 40,000 & 40,000 \\
\hline Lusail & 80,000 & Unknown \\
\hline Al Thumama & 40,000 & 20,000 \\
\hline Al Ryyan & 40,000 & 21,000 \\
\hline Qatar Foundation & 40,000 & 25,000 \\
\hline Abu Ras Abboud & 40,000 & Unknown \\
\hline Al Wakrah & 40,000 & 20,000 \\
\hline Al Khor & 60,000 & 38,000 \\
\hline & 380,000 & $284,000^{*}$ \\
\hline
\end{tabular}

*Lusail and Abu Ras Abboud are considered with full capacity, as there are no data available.

In addition, the cost of the downscale of the stadiums is another factor to take into account.

Too often mega events culminate in economic disasters, where the interest of few private entities prevails over the interest of the public collective. In this sense, Qatar should remember the importance of designing for a specific site, taking into account local needs, but also local culture, materials, and traditions. Planning according to the local vocation of each area is the only way to achieve long and sustainable positive legacies. Al Khor, Al Thumama, and Al Wakhra precincts have a strong residential and mixed-use vocation, especially for low-income families; QF precinct has a strong research and education focus, while the Aspire Zone is the sports hub of Doha. Lusail is another mixed-use neighbourhood, but more oriented to high-income expats, while Al Rayyan seems to have a commercial and leisure target. Finally, the Ras Abu Abboud area has a strong touristic potential, and it should be developed as a touristic hub. The Aspire Zone and Education City are probably the best successful areas from a vocational point of view. To illustrate, the Aspire Zone is already Doha's sports city. The precinct already holds the major sports venues of Doha, a park and open spaces, commercial (two malls) and touristic (two five-star hotels) facilities. The addition of two metro stops will make the area more accessible to residents and tourists, while the upgraded stadium (Hamad Bin Khalifa) will allow more international sports events and competitions to be hosted.

Similarly, QF has a strong vocation in education and research, as this area houses research centres, American and European universities and the major national convention centre. With the addition of a metro line, and stop, the precinct will be more accessible to students, faculty and staff members, while the stadium will complete the sport equipment available in the campus. According to SC, the stadium will be downscaled to 25,000 seats in the legacy mode. However, the capacity appears to be still too wide for a stadium that is located in a university campus, and SC should consider an additional downscale to avoid higher maintenance costs. The Lusail district also has a clear vocation, as it is an mixed-use development under construction that will be dedicated to high-income expats and families. Once finished, the neighbourhood is planned to host about 200,000 residents and 170,000 employees. It will also be 
accessible from both the red metro line and a light rail scheme and intended to include sustainability principles into the core of its master plan (Lusail City, 2016). The district will include residential, commercial, office spaces as well as dedicated areas to sport and district. However, according to its master plan, there are no schools or hospitals planned. In addition, Lusail is centred on the new stadium, a facility of 80,000 built from scratch that will host the final of the 2022 tournament. With legacy plans not yet unveiled, it will be crucial to integrate the venue within the surroundings. Regarding its function, it is unlikely that it will be used frequently as a football stadium. Indeed, there are already enough stadiums in the city to satisfy the local football needs. Most likely, the venue should be used for leisure and entertainment, for example, for hosting concerts or shows. The capacity should be adapted accordingly, for example utilising removable seats. Restaurants, entertainment and leisure spaces should also be added inside the stadium. The Al Rayyan precinct suggests creating a commercial and leisure vocation, as well as a sport destination. To illustrate, the biggest and more luxurious shopping centre in Qatar, the Mall of Qatar, opened in December 2016 exactly beside the stadium, where, after the tournament, the Al Rayyan sports club will play and train. As this area is located outside Doha (about $30 \mathrm{~km}$ in the west of Doha's downtown) and is sparsely populated (Figure 139), it is strongly suggested to add real estate projects with the development.

Ras Abu Abboud shows a strong touristic vocation. The area stands by the sea, between the airport and the old port, which will be soon reconverted to a touristic port. Two five-star hotels are also located in its vicinity, while attractions such as Souq Waqif, Corniche, the national museum, and the museum of Islamic art are within a short distance. The stadium will probably not be needed anymore after the tournament, and should be built as a complete temporary structure, and replaced with hotels, open spaces, and other touristic services. The 1992 Olympic Games in Barcelona could be a good example to look at. Indeed, this is probably one of the best examples of urban transformations of the last thirty years, and a perfect illustration of how to leverage an international event to change and improve the public space. The Games were utilised to overcome the lack of a development plan of the coastal area of Barcelona, and to open the city towards the sea. Similar to Barcelona, this area of Doha should invest in the renovation of its waterfront and link it with the Corniche and the downtown area. More difficult is the situation of Al Wakrah, Al Khor, and Al Thumama districts. All these areas have a clear residential vocation and low or middle-income expats and families inhabit them. Also, in the case of Wakrah and Khor, the majority of the population lives in labour camps. In order to develop these areas, the government should build schools, hospitals, mosques, shops, and all the services necessary to residents. Another issue is the lack of integration with the public transport. To illustrate, Al Khor is about $60 \mathrm{~km}$ from Doha and will not be connected by the new metro system. Al Wakrah will have a stop on the red line, but it will be about $7 \mathrm{~km}$ far from the stadium's precinct. Similarly, Al Thumama cannot be reached by the metro system. Those who are the most in need will be excluded from an easy access to public transport, de facto increasing the social divide among the different strata of the population. 


\section{Unplanned or unintended events}

A final factor to consider is the response to unplanned or unintended circumstances. This kind of mega events is usually planned at least seven years in advance. During this time span, many changes in the political, social, or economic situation of hosting countries can occur. For example, Qatar was awarded the 2022 World Cup at the end of 2010, when it was at the highest point of its economic success. However, in 2015, because of the rapid collapse of oil prices, Qatar's economic situation changed dramatically, and the country closed the 2015 financial year with a deficit for the first time in 15 years (Gulf Times, 2016). To illustrate, for Qatar, the fiscal break-even price of oil, which is the price that balances an oil-exporting country's budget, is about 70 USD per-barrel (The National, 2015), while, in 2016, the average price per-barrel was only 48 USD and this led Qatar to accumulate a deficit of I 3 billion USD. In addition, forecasts predict that the country will face deficit until 2019 at the least. To face the economic crisis, the Government has undertaken measures that include cutting down on or postponing important mega projects, downsizing plans in many governmental companies, and the introduction of a new taxation system (Doha News, 2016e, $2016 \mathrm{f}$, 2016i). In addition, the Government unveiled that plans for the National Development Strategy 2017-2022 include, besides completing all 2022 World Cup-related projects and infrastructure, "cutting the fat in government", by shifting some responsibility from the state onto the private sector, and "transitioning from a nation of simple social welfare policies to a state of action by empowering citizens" (Doha News, 2016h). These facts underline how the approach of utilising mega-events for urban development and regeneration can be extremely risky. In the case of Doha, the World Cup was intended to accelerate the transformation of the city, promote sustainable initiatives as a new public transport system and catalyse the implementation of the 2030 Qatar National Vision, the country's blueprint. However, the economic crisis that hit the Gulf Region in mid-2015 has led the government to redefine the country's priorities. Many initiatives and projects have been cancelled; but the entire infrastructure related to the World Cup, like the construction of eight new stadiums, has not been touched because it is part of the obligations imposed by FIFA. While the Cup was supposed to trigger beneficial urban change, it has now transformed into a boomerang effect, fostering the proliferation of white elephants and unnecessary urban infrastructure.

\section{Conclusion}

The analysis of the stadiums' precincts revealed a series of issues related to their postevent use, in particular regarding their function, capacity, costs, and integration within the urban fabric. Indeed, this kind of events always generates huge debts and bulky, complex sports structures that are expensive to build and maintain. One way to partially mitigate those issues is to leverage the vocation of each stadium's neighbourhood, by transforming the stadiums and their precincts according to local needs.

Each city (or country) has to develop a strategy that fits their characteristics and peculiarities. However, some recurrent mistakes and bad habits emerged as recurrent: the low proportion of temporary structures, the exorbitant costs, the inability to respond to unforeseen circumstances, and the lack of attention to local needs. With 
regards to the 2022 World Cup, the previous sections highlighted some major issues, as the weak legacy plans for the stadiums' precincts, the need to improve local planning capacity, exorbitant costs to build the event infrastructure and the eight new stadiums. Mega-events planning is a controversial form of urban policymaking because despite its wide impact on cities, this impact is often more negative than positive.

The research showed how difficult it is to benefit from the stage of mega events and unveiled important issues to consider before bidding. Indeed, those events are very expensive in terms of costs, effort, resources, and people, and cities need to maximise the benefits and limit the damages from their hosting. The study showed that there is potential to realise sports-oriented areas and open spaces from event sites that are fully integrated within hosting cities; however, the locations chosen for the event need to be carefully selected according to the morphology and needs of the hosting city.

The right mix of temporary, new, and already existing venues; the balance between sport and city infrastructure; the strict control of expenditure and the respect of the local vocation are some of the most important challenges cities need to face and solve. In this, FIFA, IOC and other major event organisations have to clarify their role and advocate all the initiatives that are necessary to promote and support beneficial outcomes and positive legacies.

The research aimed at contributing to the discourse on mega sports events and their impact on the built environment, and it is hoped that this work will help future hosting cities to avoid recurrent mistakes and malpractices and build their positive legacies.

\section{Acknowledgement}

This article was made possible by grant \# GSRA I-I - I I I9- I 3007 from the Qatar National Research Fund (a member of Qatar Foundation). The findings achieved herein are solely the responsibility of the author.

\section{References}

Adham, K. (2008). Rediscovering the Island: Doha's Urbanity from Pearls to Spectacle. In Elsheshtawy, Y. (ed.) The Evolving Arab City: Tradition, Modernity and Urban Development. New York: Routledge.

Amara, M. (2005). 2006 Qatar Asian Games: A ‘Modernization’ Project. Sport in Society: Cultures, Commerce, Media, Politics, Vol.8(3), pp.493-5I4.

Azzali S (2019a) Mega sporting events as tools of urban redevelopment: lessons learned from Rio de Janeiro. Proceedings of the Institution of Civil Engineers (ICE): Urban Design and Planning, 172 (3). Pp. 8I-89

Azzali, Simona (2019b) Challenges and key factors in planning legacies of mega sporting events: lessons learned from London, Sochi, and Rio de Janeiro. Archnet-IJAR: International Journal of Architectural Research. (In Press)

Azzali, S. (2017a). The legacies of Sochi 2014 Winter Olympics: an evaluation of the Adler Olympic Park. Urban Research \& Practice, Vol. I0(3), pp 329-349.

Azzali, S. (20I7b). Mega-events and urban planning: Doha as a case study. Urban Design International. Vol.22(I), Pp 3-I2.

Azzali, S. (2016). The Aspire Zone in Doha: A post-occupancy evaluation of the long-term legacies of the 2006 Asian Games. Journal of Urban Regeneration \& Renewal, Vol.9(4), pp. 393-405. 
Azzali, Simona, and Tomba, Mattia (2018) Urban development and planning practice in Doha. Middle East Journal, 180.

Brown, A., O'Connor, J., \& Cohen, S. (2000). Local music policies within a global music industry: Cultural quarters in Manchester and Sheffield, Geoforum, Vol.3I (4), pp.437-45I.

Carmona, M. (20I0). Contemporary public space, part two: classification, Journal of Urban Design, Vol.I5(2), pp.I57-173.

Carrière, J. \& Demaziere, C. (2002). Urban Planning and Flagship Development Projects: Lessons from Expo 98, Lisbon. Planning Practice and Research. 17, I, 69-79.

Doha News (20II). Qatar's World Cup will cost $\$ 220$ bn - What does that mean? Retrieved from http://dohanews.co/qatars-world-cup-will-cost-220bn-what-doesthat/

Doha News (2016a). FIFA exec warns against building 'white elephant' World Cup stadiums. Retrieved from http://dohanews.co/fifa-exec-warns-against-building-whiteelephant-worldcup-stadiums/

Doha News (2016b). Stadiums to house Qatar residents in the event of a national emergency. Retrieved from http://dohanews.co/stadiums-to-house-qatar-residents-inthe-event-of-anational-emergency/

Doha News (2016c). Experts: Qatar businesses should start preparing for VAT now. Retrieved from http://dohanews.co/experts-qatar-businesses-should-startpreparing-for-vat-now/

Doha News (2016d). Stadiums to house Qatar residents in the event of a national emergency. Retrieved at http://dohanews.co/stadiums-to-house-qatar-residents-in-the-event-of-anational-emergency/

Doha News (2016e). Experts: Qatar businesses should start preparing for VAT now. Retrieved from http://dohanews.co/experts-qatar-businesses-should-start-preparing-for-vat-now/

Doha News (2016f). Timeline for Gulf Rail project pushed back three years to 202I. Retrieved from http://dohanews.co/timeline-gulf-rail-project-pushed-back-three-years-202I/

Doha News (2016g). Work on multibillion-riyal Doha sewer project suddenly halted. Retrieved from http://dohanews.co/work-on-multibillion-riyal-doha-sewer-project-suddenly-halted/

Doha News (2016h). Emir: Time to move Qatar's people off of social welfare and into action. Retrieved from http://dohanews.co/emir-time-to-move-qatars-people-off-of-social-welfareand-into-action/

Doha News. (20I6i). Qatar World Cup organizers issue tender for football fan desert camp. Retrieved from http://dohanews.co/qatar-world-cup-organizers-issue-tender-for-footballfan-desert-camp/

Doha News (2017). Qatar gets until November to improve its human rights record. Retrieved from https://dohanews.co/qatar-gets-november-improve-human-rights-record/

Elsheshtawy, Y. (20I I). Informal encounters: mapping Abu Dhabi's urban public spaces, Built Environment, Vol.37(I), pp.92-II3.

Essex, S. \& Chalkley, B. (1999). Olympic Games: catalyst of urban change. Leisure Studies, Vol. I7(3), pp. I87-206.

Fédération Internationale de Football Association - FIFA (2010). FIFA World Cup, Qatar BiD evaluation Report. Retrieved from www.fifa.com/mm/document/tournament/competition/0 1/33/74/56/b9qate.pdf

Gehl, J. (1987). Life between buildings: using public space. New York: Van Nostrand Reinhold Company.

Gulf Times (2016). Qatar's 2016 budget foresees 'first deficit' in 15 years. Retrieved from http://www.gulf-times.com/story/487042/Qatar-s-2016-budget-foresees-first-deficit-in-I5-y

Leopkey, B. (2013). The Governance of Olympic Games Legacy, PhD Dissertation, School of Human Kinetics Faculty of Health Sciences University of Ottawa, Canada.

Lusail City (2016) Lusail City. Retrieved from http://www.lusail.com/who-we-are/ceo-message/ 
Ministry of Development Planning and Statistics (2015). First Section Population and Social Statistics. Retrieved from http://www.mdps.gov.qa/en/statistics/Statistical\%20Releases/Population/Population/2015/I_ Population_2015.pdf

Müller, M. (20I4). After Sochi 20I4: costs and impacts of Russia's Olympic Games. Eurasian Geography and Economics, Vol.55(6), pp.628-655.

Müller, M. (20I5). The Mega-Event Syndrome: Why So Much Goes Wrong in Mega-Event Planning and What to Do About It. Journal of the American Planning Association. Vol.(8I)I, Pp.6-17.

Pitts, A., \& Liao, H. (2009). Sustainable Olympic Design and Urban Development, New York: Routledge.

Qatar Statistics Authority - QSA (2015). Population structure. Retrieved from http://www.qsa.gov.qa/eng/

Qatar General Secretariat of Development Planning - QSDP (2009). Qatar National Vision 2030. Advancing Sustainable Development, Qatar's Second Human Development Report, Doha: Gulf Publishing and Printing Company.

Qatar Gulf News (20I0). The 2022 World Cup. Retrieved from http://www.qatargulfnews.com/34I-2/

Qatar Tourism Authority - QTA (2014). Activities, Retrieved from http://www.qatartourism.gov.qa/en-us/thingstodo/activities/sport.aspx

Salama, A.M., \& Azzali, S. (20I5). Examining attributes of urban open spaces in Doha. Proceedings of the ICE - Urban Design and Planning, Vol. I68(2), pp.75-87.

Smith, A. (2010). The Development of "Sports-City" Zones and Their Potential Value as Tourism Resources for Urban Areas, European Planning Studies, Vol. I8(3), pp.385- 4I0.

Smith, A. (2012). Events and Urban regeneration, New York: Routledge.

The Supreme Committee for Delivery and Legacy - SC, 2016a. Stadiums. Retrieved from http://www.sc.qa/en/stadiums

The Supreme Committee for Delivery and Legacy - SC. (2015). Al Rayyan Stadium deconstruction successfully completed. Retrieved from http://www.sc.qa/en/news/alrayyan_stadium_deconstruction

The Supreme Committee for Delivery and Legacy - SC. (20I6a). Stadiums. Retrieved from http://www.sc.qa/en/stadiums

The Supreme Committee for Delivery and Legacy - SC. (2016b). Al Bayt Stadium in AI Khor. Retrieved from http://www.sc.qa/en/news/construction-advancing-on-albayt-stadium-bowlat-proposed-semi-final venue-for-2022

The Supreme Supreme Committee for Delivery \& Legacy - SC. (2016 c). About us. Retrieved at http://www.sc.qa/en/about/vision-mission-values

The Telegraph (20II). Qatar World Cup in 2022 could cost $£$ I 38 billion according to financial analyst. Retrieved from http://www.telegraph.co.uk/sport/football/worldcup/874993I/Qatar-World-Cup-in-2022could-cost-I38-billion-according-tofinancial-analyst.html

The National (2015). How GCC states' break-even oil prices stack up. Retrieved from http://www.thenational.ae/business/energy/how-gcc-states-break-even-oil-prices-stack-up

The World Bank (20I5a). GDP (current US\$). Retrieved from http://data.worldbank.org/indicator/NY.GDP.MKTP.CD?name_desc=false

The World Bank (20I5b). Gross domestic product 20I5. Retrieved from http://databank.worldbank.org/data/download/GDP.pdf

Time (2013). Why Qatar is Spending $\$ 200$ Billion On Soccer. Retrieved from http://keepingscore.blogs.time.com/2013/07/I I/why-qatar-is-spending-200-billion-onsoccerl 